\title{
Üniversite Öğrencilerinin Üriner İnkontinans Farkındalıkları ve Benlik Saygıları Arasındaki İlişki
}

\author{
Özge ÖZ YILDIRIM*, Dilek ÇELIK EREN**, Mehmet KORKMAZ***, İlknur AYDIN AVCI*****
}

\begin{abstract}
Öz
Giriş: Üriner inkontinans prevalansı yüksek, önemli bir sağlık sorunudur. Bu sorun, bireylerin hayat kalitelerini düşürerek benlik saygılarını olumsuz etkilemektedir. Amaç: Bu araştırma, üniversite öğrencilerinin üriner inkontinans farkındalıkları ve benlik saygıları arasındaki ilişkiyi belirlemek amacıyla yapılmıştır. Yöntem: Bu çalışma, ilişki arayan tanımlayıcı araştırma ilkelerine uygun olarak bir Üniversitenin Hemşirelik, Ebelik ve Sosyal Hizmet bölümlerinde öğrenim gören 646 öğrenci ile yapılmıştır. Veriler "Tanıtıcı Soru Formu”, "Rosenberg Benlik Saygısı Ölçeği” ve "İnkontinans Farkındalık Ölçeği” kullanılarak toplanmıştır. Verilerin değerlendirilmesinde tanımlayıcı istatistikler, bağımsız gruplarda t testi, Anova testi, Tukey testi, Mann Withney U testi ve korelasyon analizleri kullanılmıştır. Araştırma gerekli izinler alınarak yapılmıştır. Bulgular: Çalışma kapsamındaki öğrencilerin yaş ortalaması $20.4 \pm 1.75$ 'dir. Öğrencilerin \%28.8'i idrar kaçırmayı deneyimlemişlerdir. Araştırma kapsamındaki kadın öğrencilerin sağlık sorunu olarak kabulünü engelleyen faktörler ve kısıtlanma alt boyut puanları erkek öğrencilere göre daha yüksektir. Erkek öğrencilerin sağlık motivasyonu ve üriner inkontinansla başetme alt boyut puanları kadın öğrencilere göre daha yüksek olup aralarındaki fark istatistiksel olarak anlamlı bulunmuştur $(\mathrm{p}<.05)$. Üriner inkontinans farkındalık ölçeği, sağlık sorunu olarak kabulünü engelleyen faktörler alt boyutu ile benlik saygısı ölçeği arasında negatif yönlü bir ilişki vardır. Sağlık motivasyonu ve kısıtlanma alt boyutu ile benlik saygısı ölçeği arasında pozitif yönlü ilişki vardır. Her iki ilişki de istatistiki olarak anlamlı bulunmuştur. Sonuç: Araştırma kapsamındaki öğrencilerin üriner inkontinans farkındalık ölçeği, sağlık sorunu olarak kabulünü engelleyen faktörler, üriner inkontinans ile başetme ve idrar korkusu yaşama alt boyutları orta düzeydedir. Öğrencilerin sağlık motivasyonu alt boyutu kötü düzeyde ve kısıtlama alt boyutu iyi düzeyde olduğu bulunmuştur. Üriner inkontinans yaşayan öğrencilerin benlik saygıları ise düşük düzeyde bulunmuştur.
\end{abstract}

Anahtar kelimeler: Üriner İnkontinans, Benlik Saygısı, Farkındalık.

\section{Abstract \\ The relationship between university students' urinary incontinence awareness and self-esteem}

Background: Urinary incontinence is an important health problem with a high prevalence. This problem affects self-esteem negatively by decreasing the quality of life of individuals. Objectives: This research was carried out to determine the relationship between urinary incontinence awareness and self-esteem of university students. Methods: This descriptive correlational study was carried out with 646 students attending in the Nursing, Midwifery, Social Work department of a University. The data were collected by using "Introductory Information Form", "Rosenberg Self-Esteem Scale" and "Incontinence Awareness Scale". Descriptive statistics, independent sample - $\mathrm{t}$ test, Anova test, tukey test, Mann Withney U and correlation analysis were used to evaluate the data. The research was conducted by taking necessary permission. Results: The mean age of the students was $20.4 \pm 1.75 .28 .8 \%$ of the students experienced urinary incontinence. The factors that prevent the acceptance of male students who experienced urinary incontinence as a health problem and the sub-dimension scores of coping with urinary incontinence were higher than the female students and the difference between them was statistically significant $(\mathrm{p}<.05)$. A negative correlation was found between the factors that prevented the acceptance of the urinary incontinence scale as a health problem, and a positive correlation between the self-esteem scale of the health motivation and restriction subscale and the self-esteem scale. Conclusion: It was determined that the factors preventing the acceptance of urinary incontinence awareness scale as health problem, coping with urinary incontinence, experiencing urinary fear subscales were moderate, health motivation subscale was poor and restriction subscale was good. It was found that students with urinary incontinence had low self-esteem.

Key words: Urinary İncontinence, Self-esteem, Awareness.

Geliş tarihi: 15.05.2019 Kabul tarihi: 03.07.2020

$\mathrm{U}$ luslararası Kontinans Topluluğunun (ICS) tanımına göre üriner inkontinans (Üi); istemsiz olarak herhangi bir idrar kaçırma şikayetidir (1). Üriner inkontinansın gelişmesinde yaş, gebelik, menopoz, vajinal doğum, obezite, histerektomi, sosyal alışkanlıklar gibi risk faktörleri bulunmaktadır (2-5). Türkiye'de tüm yaş gruplarında \%18 - 45 arası farklı oranlarda görülen üriner inkontinansın (6-9), Dünyada cinsiyete göre dağılımına bakıldığında, erkeklerde üriner inkontinans görülme prevalansının ABD'de \%44.9, İngiltere'de \%50.5 ve İsveç'te \%39.4; kadınlarda ABD'de \%67, İngiltere'de \%69 ve İsveç’te \%67.1 olduğu ifade edilmektedir (10). Gençlerle yapıllan çalışmalarda üriner inkontinans prevalansı \%6.2-12.4 arasında değişmektedir $(11,12)$.

Bireylerin üriner inkontinans konusundaki farkındalıklarının düşük olduğu ve bu sorunu yaşadıklarında profesyonel yardım almak yerine kendilerinin baş etmeye çalıştıkları görülmektedir (13-16). Bu durum üriner inkontinans sorununu daha karmaşık hale getirmekte ve bireylerin günlük yaşamlarını etkileyerek yaşam kalitelerini düşürmektedir $(7,16)$. Yetişkinlerde yaşam kalitesine etkileri olan üriner inkontinans, üniversite öğrencilerinde de yaşam kalitesini oldukça etkilemektedir. Szymanski ve arkadaşlarının (2018) yaptıkları çalışmada, üriner inkontinansın bireylerin yaşam kalitelerini etkilediği sonucunu

Bu araştırma, 23-26 Nisan 2018 tarihinde Ankara'da düzenlenen, I. Uluslararası ve II. Ulusal Halk Sağlığı Hemşireliği Kongresi'nde poster bildiri olarak sunulmuştur. * Arş.Gör. Ondokuz Mayıs Üniversitesi Sağlık Bilimleri Fakültesi Hemşirelik Bölümü, Halk Sağlığı Hemşireliği Anabilim Dalı, Samsun. E-posta: ozge.oz@omu.edu.tr, ORCID: https://orcid.org/0000-0003-4810-563X ** Arş.Gör. Ondokuz May1s Üniversitesi Sağlık Bilimleri Fakültesi Hemşirelik Bölümü, Halk Sağlığı Hemşireliği Anabilim Dalı, Samsun. E-posta: dilek.celik@omu.edu.tr, ORCID: https://orcid.org/0000-0002-9439-1641. *** Arş.Gör. Ondokuz Mayıs Üniversitesi Sağllk Bilimleri Fakültesi Hemşirelik Bölümü, Halk Sağlığı Hemşireliği Anabilim Dalı, Samsun. E-posta: mehmet.korkmaz@omu.edu.tr, ORCID: https://orcid.org/0000-0003-0241-2466 **** Prof. Dr. Ondokuz Mayıs Üniversitesi Sağlık Bilimleri Fakültesi Hemşirelik Bölümü, Halk Sağlığı Hemşireliği Anabilim Dalı, Samsun. E-posta: ilknura@omu.edu.tr, ORCID: https://orcid.org/0000-0002-5379-3038 
bulmuşlardır (17). Ayrıca üriner inkontinans yaşayan bireylerle yapılan çalışmalarda bireylerin davranış problemleri, duygusal distres, düşük yaşam kalitesi ve düşük benlik saygısı gibi sorunlar yaşadığı belirlenmiştir (18-20).

Üniversitede eğitim alma dönemindeki gençler benliklerini tamamlamaya çalışmaktadırlar. Gençler bu dönemi ne kadar sağlıklı geçirirlerse benlikleri de o kadar sağlıklı şekillenmektedir. Bu dönemde deneyimledikleri olumsuz durumlarla sağlıklı bir şekilde baş edemeyen gençler benliklerini tamamlamakta sorunlar yaşamaktadırlar. Bu süreç, gençlerin benliklerine olumlu ya da olumsuz etki etmektedir. Üriner inkontinans sıklıkla bir sağlık problemi olarak kabul edilmeyip bir yetersizlik olarak algılanabildiği için, üriner inkontinans gibi olumsuz bir durumun bu dönemde yaşanması benlik saygısı üzerinde olumsuz etkiler meydana getirecektir (17). Bu çalışma ile üniversite öğrencilerinin üriner inkontinans farkındalıkları ve benlik saygıları arasındaki ilişkinin belirlenmesi amaçlanmaktadır.

Araştırmanın soruları:

- Üniversite öğrencilerinin üriner inkontinans farkındalıkları ile benlik saygıları arasındaki ilişki var mıdır?

- Üniversite öğrencilerinin idrar kaçırma durumları ile üriner inkontinans farkındalıkları arasında ilişki var mıdır?

- Üniversite öğrencilerinin idrar kaçırma durumları ile benlik saygıları arasında ilişki var mıdır?

\section{Yöntem}

\section{Araştırmanın Tipi}

$\mathrm{Bu}$ araştırma ilişki arayan tanımlayıcı araştırma ilkelerine uygun olarak yapılmıştır.

\section{Araştırmanın Yapıldı̆̆ Yer ve Zaman}

Araştırma Ocak 2018-Nisan 2018 tarihleri arasında bir üniversitenin Hemşirelik, Ebelik ve Sosyal Hizmet bölümlerinde öğrenim gören öğrenciler ile yapılmıştır.

\section{Araştırmanın Değişkenleri}

Bağımlı değişken: çalışma kapsamındaki öğrencilerin inkontinans farkındalıkları ve benlik saygıları

Bağımsız değişken: çalışma kapsamındaki öğrencilerin sosyo-demografik özellikleri, inkontinans deneyimleme durumları.

\section{Araștırmanın Evren ve Örneklemi}

Araştırmanın evrenini bir üniversitede, sağlık alanında öğrenim gören 1121 öğrenci oluşturmaktadır. Çalışmada örneklem seçimine gidilmeyip araştırmaya katılmayı kabul eden tüm öğrencilerle yapılması planlanmış ve çalışma 646 (\%57.6) öğrenci ile tamamlanmıştır. Araştırmaya katılmak istemeyen, veri toplama formunda hata tespit edilen, araştırmanın yapıldığı tarihlerde izinli ya da raporu olanlar kapsam dışı bırakılmıştır.

\section{Veri Toplama Araçlart}

Veri toplama işlemi araştırmacılar tarafından geliştirilmiş, sosyo-demografik özellikler ve inkontinans ile ilgili 13 sorudan oluşan "Tanıtıcı Soru Formu”, 10 sorudan oluşan "Rosenberg Benlik Saygısı Ölçeği” ve 26 sorudan oluşan "İnkontinans Farkındalık Ölçeği” kullanılarak sınıflarda anketler öğrencilere araştırmacılar tarafından dağıtılmış ve ortalama 15-20 dakikada tamamlanmıştır.

\section{Tanitıce Soru Formu}

Araştırmacılar tarafından oluşturulan bu form yaş, cinsiyet, medeni durum, okuduğu bölüm, sınıf, çalışma durumu, gelir durumu, idrar kaçırmayı deneyimleme durumu, idrar kaçırmayı deneyimleme zamanı, idrar kaçırılan durum, idrar kaçırdığında yapılan şey, ailesinde idrar kaçırma sorununu deneyimlemiş bireylerin olma durumu ve ailede idrar kaçıran birey sorularını içermektedir.

Rosenberg Benlik Saygısı Ölçeği

Rosenberg tarafından 1965 yılında geliştirilen ölçeğin, 1985 yılında Çuhadaroğlu tarafından Türkçeye geçerlik güvenirliği yapılmıştır (22-23). Benlik saygısı ölçeği, ters ölçüm yapan 3. 5. 8. 9. 10. maddeleri ve normal ölçüm yapan 1. 2. 4. 6. ve 7. maddelerinde oluşan 10 soruluk ölçektir. Ölçeğin Sorular Guttman değerlendirme yöntemiyle puanlanmaktadırlar. Buna göre her sorunun puan alacak yanıtları ölçek üzerinde '*' işareti ile gösterilmiştir Böylece testi dolduran kişi tüm sorulardan puan aldığı zaman maksimum puanı 6 olmaktadır.0-1 puan yüksek, 2-4 puan orta ve 5-6 puan düşük benlik saygısı düzeyi olarak saptanmıştır. Grup uygulamalarında, her bir deneğin toplam puanı bu şekilde hesaplanarak puan ortalamasıyla grubun benlik saygısı düzeyi belirlenebilir. Bu çalışmada ölçeğin puan ortalaması $1.69 \pm 1.46$ (min:0; max:6)'dır. Ölçeğin geçerlilik güvenirlik çalışmasındaki Cronbach alfa değeri:0.71'dir. Bu çalışmadaki Cronbach alfa değeri ise: 0.85 olarak bulunmuştur.

\section{Inkontinans Farkındalık Ölçeği}

Avci ve arkadaşları (2017) tarafından bireylerin idrar kaçırmaya yönelik farkındalıklarını ölçmek amacıyla geliştirilen, üriner inkontinans farkındalık ölçeği 26 maddeden oluşmaktadır (21). Ölçek; sağlık sorunu olarak kabulünü engelleyen faktörler, üriner inkontinansla başetme, sağlık motivasyonu, kısıtlanma, idrar kaçırma korkusu olmak üzere 5 alt boyuttan oluşmaktadır. Ölçekte her bir ifadeye verilen cevaplar 5'li likert tipinde; sağlık sorunu olarak kabulünü engelleyen faktörler, kısıtlanma ve idrar kaçırma korkusu alt boyutları pozitif algı, sağlı motivasyonu, üriner inkontinansla başetme alt boyutları ise negatif algıları içermektedir. Alt boyutlardan alınan puanlar; Sağlık sorunu olarak kabulünü engelleyen faktörler alt boyutu için (8-40); Sağl1k motivasyonu alt boyutu için (5-25); üriner inkontinansla başetme alt boyutu için (6-30); kısıtlanma alt boyutu için (315); idrar kaçırma korkusu alt boyutu için (4-20)'dir. Ölçeğin toplam puanı yoktur. Sağlık sorunu olarak kabulünü engelleyen faktörler, kısıtlanma ve idrar kaçırma korkusu alt boyutları negatif algı, sağlık motivasyonu, üriner inkontinansla başetme alt boyutları ise pozitif algıları içermektedir. Sağlık sorunu olarak kabulünü engelleyen faktörler, kısıtlanma ve idrar kaçırma korkusu alt boyutlardan yüksek puan alınması etkilenmenin daha fazla olduğunu göstermektedir. Ölçek alt boyutlarının geçerlilik güvenirlik çalışmasındaki Cronbach alfa değerleri şu şekildedir; sağlık sorunu olarak kabulünü engelleyen 
faktörler:0.87, sağlık motivasyonu:0.92, üriner inkontinansla başetme:0.86, kısıtlanma:0.79, idrar kaçırma korkusu:0.60'dır. $\mathrm{Bu}$ çalışmada ölçek alt boyutlarının Cronbach alfa değerleri ise şu şekildedir; sağlık sorunu olarak kabulünü engelleyen faktörler:0.78, sağlık motivasyonu:0.83, üriner inkontinansla başetme:0.87, kısıtlanma:0.81, idrar kaçırma korkusu:0.84'tür. İnkontinans farkındalık ölçeği yorumlanması median puan üzerinden kötü, orta, iyi olarak yapılmaktadır.

Verilerin Dĕgerlendirilmesi

Araştırmadan elde edilen veriler bilgisayar ortamında SPSS 21.0 Programında değerlendirilmiştir. Verilerin değerlendirilmesinde tanımlayıcı istatistikler, bağımsız gruplarda t testi, Anova testi, Tukey testi Mann Withney U testi ve korelayon testleri kullanılmıştır.

Araştırmanın Etik Yönü

Araştırma 29.11.2017 tarihli (Karar No: 2017/226-271) yazılı izin, araştırma kapsamındaki öğrencilerden sözel onam alınarak yapılmıştır.

\section{Bulgular}

Çalışma kapsamındaki öğrencilerinin yaş ortalamalarının $20.4 \pm 1.75$ (min: 17; max: 32) olduğu saptanmıştır. Öğrencilerin \%84.8'inin kadın, \%98.8'inin bekar, \%57.4'ünün hemşirelik ve \%27.6'sının ebelik bölümü öğrencisi, \%32.7'sinin üçüncü sınıf, \%26.5'inin birinci sınıfta öğrenim gördüğü, \%95.7'sinin herhangi bir işte çalışmadığı ve \%69.2'sinin gelir durumunun orta düzeyde \%28.9'unun gelir durumunun iyi olduğu bulunmuştur (Tablo 1).

Tablo 1. Öğgrencilerin Sosyo-Demografik Özellikleri(n=646)

\begin{tabular}{|c|c|c|}
\hline & n & $\%$ \\
\hline Yaş & \multicolumn{2}{|c|}{$20.4 \pm 1.75(\min : 17 ; \max : 32)$} \\
\hline \multicolumn{3}{|l|}{ Cinsiyet } \\
\hline Kadın & 548 & 84.8 \\
\hline Erkek & 98 & 15.2 \\
\hline \multicolumn{3}{|l|}{ Medeni durum } \\
\hline Evli & 8 & 1.2 \\
\hline Bekar & 638 & 98.8 \\
\hline \multicolumn{3}{|l|}{ Bölüm } \\
\hline Hemşirelik & 371 & 57.4 \\
\hline Ebelik & 178 & 27.6 \\
\hline Sosyal hizmet & 97 & 15 \\
\hline \multicolumn{3}{|l|}{ Sinıf } \\
\hline 1 & 171 & 26.5 \\
\hline 2 & 138 & 21.4 \\
\hline 3 & 211 & 32.7 \\
\hline 4 & 126 & 19.4 \\
\hline \multicolumn{3}{|c|}{ Calışma durumu } \\
\hline Çalışıyor & 28 & 4.3 \\
\hline Çalışmıyor & 618 & 95.7 \\
\hline \multicolumn{3}{|l|}{ Gelir durumu } \\
\hline İyi & 187 & 28.9 \\
\hline Orta & 447 & 69.2 \\
\hline Kötü & 12 & 1.9 \\
\hline
\end{tabular}

Çalışma kapsamındaki katılımcıların \%71.2'sinin idrar kaçırma problemini deneyimlemedikleri, idrar kaçıranların \%63.4'ü ilk kez ilkokulda, \%35.5'i idrara sıkışıp tuvalete giderken idrar kaçırmış olup, \%60.2'si ilk kez idrar kaçırdığında hiçbir şey yapmamıştır. Öğrencilerin \%32.5'inin ailesinde idrar kaçıran bireyin bulunduğu; bunların \%47.1'inin anne/babasının, \%41.9'unun büyükanne/büyükbabasının idrar kaçırdığı bulunmuştur (Tablo 2).

Öğrencilerin inkontinans farkındalık ölçeği alt boyutlarından sağlık sorunu olarak kabulünü engelleyen faktörler alt boyutu toplam puan ortalamaları $29.7 \pm 5.92$, sağlık motivasyonu alt boyut toplam puan ortalamaları $9.14 \pm 3.60$, üriner inkontinansla baş etme alt boyut toplam puan ortalamaları $16.51 \pm 4.91$, kisitlanma alt boyut toplam puan ortalamaları $10.36 \pm$ 3.06 ve idrar kaçırma korkusu alt boyut toplam puan ortalamaları $11.54 \pm 4.12$ benlik saygısı toplam puan ortalamaları $1.69 \pm$ 1.46 'ydi (Tablo 3).

Araştırma kapsamına alınan öğrencilerin cinsiyetleri ile sağlık motivasyonu, üriner inkontinansla baş etme ve kısıtlanma alt boyut toplam puan ortalamaları arasında istatistiksel açıdan anlamlı bir fark olduğu belirlenmiştir (p $<.05$ ). Öğrencilerin öğrenim gördükleri bölüm ile üriner inkontinansla başetme toplam puan ortalamaları arasında bir fark olduğu bu farkın istatistiksel açıdan anlamlı olduğu $(\mathrm{p}<.05)$ ve bu farkın ebelik ve sosyal hizmet bölümlerinde öğrenim gören öğrencilerin puan farklarından kaynaklandığg saptanmıştır (Tablo 4).

Araştırma kapsamındaki öğrencilerin öğrenim gördükleri sınıf ile sağlık sorunu olarak kabulünü engelleyen faktörler ve üriner inkontinansla başetme toplam puan ortalamaları arasında istatistiksel açıdan anlamlı bir farkın olduğu (p < .05) ve 
ikinci ve dördüncü sınıflarda öğrenim gören öğrencilerin toplam puan ortalamalarının bu farka neden olduğu belirlenmiştir (Tablo 4).

Öğrencilerin idrar kaçırma durumları ile sağlık sorunu olarak kabulünü engelleyen faktörler, üriner inkontinansla baş etme alt boyutları ve benlik saygısı toplam puan ortalamaları arasında istatistiksel açıdan anlamlı bir farkın olduğu saptanmıştır $(\mathrm{p}<.05)$. İdrar kaçıran öğrencilerin sağlık sorunu kabulünü etkileyen faktörler ve üriner inkontinansla baş etme alt boyutları toplam puan ortalamalarının daha düşük olduğu; idrar kaçırmayanların benlik saygısı toplam puan ortalamalarının daha düşük olduğu bulunmuştur (Tablo 4).

Öğrencilerin ailelerinde idrar kaçıran birey bulunma durumları ile üriner inkontinansla baş etme ve kısıtlanma alt boyut toplam puan ortalamaları arasında istatistiksel açıdan anlamlı bir farkın olduğu saptanmıştır $(\mathrm{p}<.05)$. Ailelerinde idrar kaçıran birey bulunmayan öğrencilerin üriner inkontinansla baş etme alt boyut toplam puan ortalamaları ve ailelerinde idrar kaçıran birey bulunan öğrencilerin kısıtlanma alt boyut toplam puan ortalamalarının daha yüksek olduğu bulunmuştur (Tablo 4).

Tablo 2. Öğrencilerin Üriner İnkontinans ile ilgili Özellikleri $(n=646)$

\begin{tabular}{lcc}
\hline & $\mathbf{n}$ & $\mathbf{\%}$ \\
\hline İdrar kaçırmayı deneyimleme durumu & & \\
Hayır & 460 & 71.2 \\
Evet & 186 & 28.8 \\
\hline İdrar kaçırmayı deneyimleme zamanı (n=186) & & \\
İkokulda & 118 & 63.4 \\
Ortaokulda & 32 & 17.2 \\
Üniversitede & 19 & 10.2 \\
Lisede & 17 & 9.2 \\
\hline İdrar kaçırılan durum (n=186) & & \\
İdrara sıkışı tuvalete giderken & 66 & 35.5 \\
Gece uykuda & 64 & 34.4 \\
Gülerken, hapşırırken & 51 & 27.4 \\
Dururken & 5 & 2.7 \\
\hline İdrar kaçırdığında yapılan şey (n=186) & & \\
Hiçbir şy yapmamış & 112 & 60.2 \\
Aileye anlatma & 64 & 34.4 \\
Arkadaşlara anlatma & 6 & 3.2 \\
Doktora başvurma & 4 & 2.2 \\
\hline Ailede idrar kaçırmayı deneyimleyen birey olma durumu & & \\
Hayır & 436 \\
Evet & 210 & 67.5 \\
\hline Ailede idrar kaçıran birey & & 32.5 \\
Anne/baba & 99 & \\
Büyükanne/büyükbaba & 88 & 47.1 \\
Kardeş & 23 & 11.9 \\
\hline
\end{tabular}

Tablo 3. Öğrencilerin İkontinans Farkındalık Alt Boyutları ve Benlik Sayısı Toplam Puan Ortalamaları (n=646)

\begin{tabular}{lc}
\hline Ölçekler & Ortalama \pm Standart Sapma (min-max) \\
\hline İnkontinans farkındalık alt boyutları & $29.7 \pm 5.92(11-55)$ \\
Sağlık sorunu olarak kabulünü engelleyen faktörler & $9.14 \pm 3.60(5-25)$ \\
Sağlık motivasyonu & $16.51 \pm 4.91(6-30)$ \\
Üriner inkontinansla başetme & $10.36 \pm 3.06(3-15)$ \\
Kısıtlanma & $11.54 \pm 4.12(4-20)$ \\
İdrar kaçırma korkusu & $1.69 \pm 1.46(0-6)$ \\
\hline Benlik saygısı
\end{tabular}

Araştırma kapsamına alınan öğrencilerin inkontinans farkındalık ölçeği alt boyutlarından sağlık sorunu olarak kabulünü etkileyen faktörler toplam puan ortalaması ile benlik saygısı toplam puan ortalaması arasında istatistiksel açıdan anlamlı, negatif yönde ve çok zayıf bir ilişkinin bulunduğu saptanmıştır $(\mathrm{p}<.05)$. Öğrencilerin sağlık motivasyonu alt boyut toplam puan ortalaması ile benlik saygısı toplam puan ortalaması arasında istatistiksel açıdan anlamlı, pozitif yönde ve çok zayıf bir ilişkinin bulunduğu belirlenmiştir $(\mathrm{p}<.05)$. Öğrencilerin kısıtlanma alt boyut toplam puan ortalaması ile benlik saygısı toplam puan ortalaması arasında istatistiksel açıdan anlamlı, pozitif yönde ve zayıf bir ilişkinin bulunduğu belirlenmiştir $(\mathrm{p}<.05)$, (Tablo 5). 
Tablo 4. Öğrencilerin Sosyo-demografik Özellikleri ve İdrar Kaçırma Durumlarına Göre Üriner İnkontinans Farkındalı̆̆ Alt Boyutları ve Benlik Saygısı Toplam Puan Ortalamalarının Karşılaşttrılması

\begin{tabular}{|c|c|c|c|c|c|c|}
\hline & $\begin{array}{c}\text { Sağlık } \\
\text { sorunu } \\
\text { olarak } \\
\text { kabulünü } \\
\text { engelleyen } \\
\text { faktörler }\end{array}$ & $\begin{array}{c}\text { Sağlık } \\
\text { motivasyonu }\end{array}$ & $\begin{array}{c}\text { Üriner } \\
\text { inkontinansla } \\
\text { başetme }\end{array}$ & Kisitlanma & $\begin{array}{l}\text { İdrar } \\
\text { kaçırma } \\
\text { korkusu }\end{array}$ & Benlik saygısı \\
\hline \multicolumn{7}{|l|}{ Cinsiyet } \\
\hline Kadın & $29.89 \pm 5.76$ & $8.98 \pm 3.57$ & $16.35 \pm 4.91$ & $10.46 \pm 3.06$ & $17.12 \pm 4.91$ & $2.74 \pm 0.80$ \\
\hline Erkek & $28.46 \pm 6.21$ & $9.99 \pm 3.69$ & $17.42 \pm 4.79$ & $9.79 \pm 3.02$ & $17.24 \pm 4.88$ & $2.88 \pm 0.83$ \\
\hline İstatistik & $\begin{array}{c}\mathrm{Z}:-2.287 \\
\mathrm{p}: .22\end{array}$ & $\begin{array}{c}Z:-2.940 \\
\text { p:.003 }\end{array}$ & $\begin{array}{c}Z:-2.432 \\
\text { p:.015 }\end{array}$ & $\begin{array}{c}\text { Z:-2.244 } \\
\text { p:.025 }\end{array}$ & $\begin{array}{c}\mathrm{Z}:-0.146 \\
\mathrm{p}: .884\end{array}$ & $\begin{array}{c}\text { Z:-0.146 } \\
\text { p:.601 }\end{array}$ \\
\hline \multicolumn{7}{|l|}{ Bölüm } \\
\hline Ebelik & $29.51 \pm 6.44$ & $8.70 \pm 3.48$ & $16.20 \pm 4.75$ & $10.53 \pm 2.91$ & $16.70 \pm 4.84$ & $1.66 \pm 1.54$ \\
\hline Hemşirelik & $29.85 \pm 5.79$ & $9.33 \pm 3.77$ & $16.37 \pm 4.71$ & $10.19 \pm 3.06$ & $17.13 \pm 4.81$ & $1.63 \pm 1.37$ \\
\hline Sosyal & $29.27 \pm 4.83$ & $9.20 \pm 3.12$ & $17.63 \pm 5.75$ & $10.69 \pm 3.30$ & $17.99 \pm 5.29$ & $1.92 \pm 1.63$ \\
\hline \multicolumn{7}{|l|}{ Hizmet } \\
\hline İstatistik & $\begin{array}{l}\text { F:0.484 } \\
\text { p:.617 }\end{array}$ & $\begin{array}{l}\text { F:1.890 } \\
\text { p:.152 }\end{array}$ & $\begin{array}{l}\text { F:3.065 } \\
\text { p:.047 }\end{array}$ & $\begin{array}{l}\text { F: } 1.420 \\
\text { p:.243 }\end{array}$ & $\begin{array}{c}F: 2.193 \\
\text { p:.112 }\end{array}$ & $\begin{array}{l}\text { F: } 1.488 \\
\text { p:.227 }\end{array}$ \\
\hline \multicolumn{7}{|l|}{ Sinıf } \\
\hline 1 & $28.37 \pm 5.57$ & $9.09 \pm 3.35$ & $16.57 \pm 4.98$ & $10.30 \pm 3.14$ & $17.36 \pm 4.63$ & $1.78 \pm 1.54$ \\
\hline 2 & $30.04 \pm 4.95$ & $9.20 \pm 3.33$ & $15.42 \pm 4.52$ & $10.06 \pm 2.97$ & $16.30 \pm 4.95$ & $1.67 \pm 1.35$ \\
\hline 3 & $30.38 \pm 5.49$ & $8.78 \pm 3.58$ & $16.76 \pm 4.90$ & $10.55 \pm 2.93$ & $17.15 \pm 4.98$ & $1.62 \pm 1.55$ \\
\hline 4 & $29.83 \pm 7.29$ & $9.72 \pm 4.18$ & $17.21 \pm 5.08$ & $10.44 \pm 3.25$ & $17.74 \pm 5.03$ & $1.67 \pm 1.31$ \\
\hline İstatistik & $\begin{array}{c}\text { F:4.117 } \\
\text { p:.007 }\end{array}$ & $\begin{array}{c}\mathrm{F}: 1.819 \\
\mathrm{p}: .142\end{array}$ & $\begin{array}{c}\text { F:3.346 } \\
\text { p:.019 }\end{array}$ & $\begin{array}{c}\mathrm{F}: 0.774 \\
\mathrm{p}: 509\end{array}$ & $\begin{array}{c}\mathrm{F}: 2.112 \\
\mathrm{p}: .097\end{array}$ & $\begin{array}{c}\mathrm{F}: 0.370 \\
\mathrm{p}: .774\end{array}$ \\
\hline \multicolumn{7}{|c|}{ İdrar kaçırma durumu } \\
\hline Evet & $28.18 \pm 5.49$ & $9.39 \pm 3.12$ & $15.80 \pm 4.59$ & $10.61 \pm 2.88$ & $17.13 \pm 4.95$ & $1.94 \pm 1.58$ \\
\hline Hayır & $30.27 \pm 5.88$ & $9.03 \pm 3.77$ & $16.80 \pm 5.00$ & $10.26 \pm 3.12$ & $17.14 \pm 4.89$ & $1.58 \pm 1.39$ \\
\hline \multirow[t]{2}{*}{ İstatistik } & $t:-4.181$ & $\mathrm{t}: 1.126$ & $t:-2.364$ & $\mathrm{t}: 1.322$ & t:-.0.029 & $t: 2.860$ \\
\hline & p:.001 & p:.261 & p:.018 & p:.187 & p:.977 & p:.004 \\
\hline \multicolumn{7}{|c|}{ Ailede idrar kaçıran birey bulunma durumu } \\
\hline Evet & $29.89 \pm 5.94$ & $8.80 \pm 3.29$ & $15.32 \pm 4.55$ & $10.72 \pm 3.08$ & $17.10 \pm 4.74$ & $1.78 \pm 1.56$ \\
\hline Hayır & $29.57 \pm 5.80$ & $9.30 \pm 3.74$ & $17.08 \pm 4.97$ & $10.19 \pm 3.04$ & $17.16 \pm 4.99$ & $1.64 \pm 1.41$ \\
\hline \multirow[t]{2}{*}{ İstatistik } & $\mathrm{t}: 0.660$ & $\mathrm{t}: 1.624$ & t:-4.340 & $t: 2.075$ & t:-0.134 & $\mathrm{t}: 1.212$ \\
\hline & p:.509 & p:.105 & p:.001 & p:.038 & p:.894 & p:.226 \\
\hline
\end{tabular}

Tablo 5. Öğrencilerin İnkontinans Farkındalık Ölçeği Alt Boyutları ile Benlik Saygısı İlișkisi

\begin{tabular}{lcc}
\hline Değişken & \multicolumn{2}{c}{ Benlik sayısı } \\
\hline İnkontinans Farkındalık Ölçeği & r & p \\
\hline Sağlık sorunu olarak kabulünü engelleyen faktörler & -.187 & $\mathbf{. 0 0 1}$ \\
Sağlık motivasyonu & .138 & $\mathbf{. 0 0 1}$ \\
Üriner inkontinansla başetme & .066 & .920 \\
Kısıtlanma & .310 & $\mathbf{. 0 0 1}$ \\
İdrar kaçırma korkusu & .012 & .766 \\
\hline
\end{tabular}

\section{Tartışma}

Üniversite öğrencilerinde üriner inkontinans prevalansı, farkındalığı ve benlik saygısının incelendiği bu çalışmada, öğrencilerin inkontinans prevalansı \%28.8 olarak bulunmuştur. Durukan ve arkadaşlarının (2015) tarafindan Mersin'de yaşayan kadınlarla yapılan bir çalışmada kadınların inkontinans prevalansı \%21.3, Lasserre ve arkadaşlarının (2009) Fransız kadınların inkontinans durumları ve yaşam kalitelerini inceleyen bir çalışmalarında kadınların inkontinans prevalansı $\% 26.8$ ve Hunskaar ve arkadaşlarının (2004) dört Avrupa ülkesinde yaşayan kadınlarla yaptıkları çalışmada kadınların inkontinans prevalansı \%23.9 olarak bulunmuştur (24-26). Bu çalışmada bulunan inkontinans prevalansı literatürdeki çalışmalarla benzerlik göstermektedir. Üniversite öğrencilerinde üriner inkontinans sıklığının yüksek olması dikkat çekici bir sonuçtur.

$\mathrm{Bu}$ çalışmada inkontinans deneyimleyen bireylerin yarısından fazlası (\%60.2) hiç bir şey yapmamış sağlık profesyonellerine başvurmamışlardır. Svihra ve arkadaşlarının (2012) Orta Avrupa ülkelerinde yaptıkları çalışmalarında 
inkontinansı deneyimleyen bireylerin yarısı (\%50) inkontinans durumunda sağlık arayışı davranışında bulunmamışlardır (27). Demir ve Beji’nin (2015) çalışmasında ise katılımcıların \%66.4'ü sağlık profesyoneline başvurmamışlardır (16). Bu çalışmada elde edilen bu sonuç literatürle paralellik göstermektedir. Bu sonucun, bireylerin üriner inkontinansı utanılacak bir durum olarak görmeleri ve sağlık personelinin olumsuz tutumundan çekinmelerinden kaynaklandığı düşünülmektedir. Bununla birlikte üriner inkontinans sıklığının yüksek olması üniversite öğrencilerinin yardıma ihtiyaç duyduklarının göstergesi olabilir.

$\mathrm{Bu}$ çalışmada üniversite öğrencilerinin üriner inkontinans farkındalıklarının orta düzeyde olduğu bulunmuştur. Luo ve arkadaşlarının (2016) Çin'de hemşirelik öğrencileriyle yaptıkları bir çalışmada inkontinans yaşayan öğrencilerin inkontinans bilgi düzeyleri düşük bulunmuştur (28).

Çalışma kapsamındaki erkek öğrencilerin üriner inkontinans farkındalık ölçeği sağlık motivasyonu ve üriner inkontinansla başetme alt boyutları kadın öğrencilerden daha iyi durumdadır. Coyne ve arkadaşlarının (2012) yaptıkları çalışmada erkeklerin kadınlara göre üriner inkontinans yaşadıklarında daha fazla tedavi arayışına girdikleri belirlenmiştir (10). Üriner inkontinans erkek bireyler için bir güç kaybı olarak algılanabilir. Bu durum erkeklik algısına atfedileceğinden, erkek öğrencilerin daha fazla yardım aramasının da nedeni olabilir. Baş etmelerini olumlu yönde etkileyebilir.

Çalışma kapsamındaki üniversite öğrencilerinin üriner inkontinans farkındalık ölçeği sağlık sorunu olarak kabulünü engelleyen faktörler algısı arttıkça benlik saygıları azalmaktadır. Üriner inkontinans deneyimleyen bireyler, bu sorun ile baş etmek için öncelikle bu sorunun tedavisi olan bir sağlık problemi olduğunun farkına varmalıdır. Bu sorunun sağlık sorunu olduğunu algılamasının önünde bulunan engeller ne kadar fazla ise kişi bu sorun ile ilgili yardım almak yerine kendi başetmeye çalışacaktır. Dolayısıyla bu sorun hayatlarında daha fazla olumsuz etki meydana getirerek benlik saygılarında azalmaya neden olabilecektir.

Çalışma kapsamındaki idrar kaçırmayan öğrencilerin kaçıranlara göre benlik saygısı daha düşük bulunmuştur. Çocuklarda yapılan bir çalışmada idrar kaçıran çocuklarda yaşam kalitesi düşük bulunmuşken, benlik saygılarında bir etkilenme görülmemiştir (29). Fouad ve Hafez'in (2017) çalışmasında idrar kaçırma süresi ne kadar uzunsa benlik saygılarının da o kadar etkilendiği belirlenmiştir (30). İdrar kaçırma sorunu her yaşta bireylerin hayatını ve benlik saygısını olumsuz etkileyebilmektedir. Bu çalışmadan çıkan sonucun öğrencilerin sosyal olarak en aktif oldukları üniversite döneminde üriner inkontinans yaşamalarının benlik saygılarını olumsuz etkilediği düşünülmektedir.

Ailelerinde idrar kaçıran birey bulunan öğrencilerin üriner inkontinansla baş etmeleri daha az, kısıtlanmaları ise daha fazladır. Bu sonuç öğrencilerin, çevrelerinde idrar kaçıran bireyleri ve onların yaşadıklarını görmelerinin, idrar kaçırma sorununu normalleştirmelerine neden olduğunu düşündürmektedir. Öğrencilerin çevrelerindeki idrar kaçıran bireyler, idrar kaçırma sorunlarına yönelik hiçbir şey yapmıyorlarsa, bunu deneyimleyen öğrencilerin de üriner inkontinans ile baş etmeleri daha yetersiz, kendilerini kısıtlamaları ise daha fazla olacaktır.

Kadın öğrencilerin üriner inkontinans farkındalık ölçeği kısıtlanma alt boyutunda daha yüksek puan aldıkları dolayısıyla idrar kaçırma sorunu yaşadıkları zaman kendilerini erkek öğrencilere göre daha fazla kısıtlayacakları belirlenmiştir. Kadınlar idrar kaçırma sorunu yaşadıklarında utandıkları için profesyonel yardım almak yerine kendileri baş etmeye çalışmaktadırlar $(15,16)$. Kadınlar idrar kaçırma sorununu yaşın ilerlemesi, doğum yapma, menopoza girme gibi nedenlerle bu sorunu normal bir durum olarak görebilmektedirler. $\mathrm{Bu}$ nedenle sağllk kuruluşuna başvurmak yerine kendilerini kısıtladıklarında bu sorun ile daha iyi baş edebileceklerini düşünebilmektedirler.

Öğrencilerinin üriner inkontinans farkındalık ölçeği kısıtlanma algıları arttıkça benlik saygıları azalmaktadır. Üriner inkontinans bireylerin yaşamında sosyal, psikolojik etkiler meydana getirerek kısıtlamalar yaşatabilmektedir. Bu durumun, bireylerin daha çok içe kapanmasına ve benlik saygılarının azalmasına neden olduğu düşünülebilir.

\section{Sonuçların Uygulamada Kullanımı}

Üniversite öğrencilerinin üriner inkontinans farkındalıklarının ve benlik saygılarının araştırıldığı bu çalışmada üriner inkontinans yaşayan öğrencilerin benlik saygılarının, üriner inkontinans yaşamayanlara göre daha yüksek olduğu bulunmuştur. Üniversite öğrencileri ile çalışan halk sağlığı hemşirelerinin, üriner inkontinans farkındalık artırma çalışmaları yapmaları ve üriner inkontinans yaşayan öğrenciler için de profesyonel sağlık yardımı almaları konusunda danışmanlık yapmaları, üniversite öğrencilerinin benlik saygılarında olumsuz değişim meydana gelmeden müdahale edilmesini sağlamış olacaktır. Üniversite öğrencilerinin üriner inkontinans farkındalıklarının araştırıldığı çalışmaların tüm üniversitelerde ve bununla birlikte tüm toplumda yapılması önerilmektedir.

\section{Kisıtlılıklar}

Bu çalışma sadece bir üniversitenin Hemşirelik, Ebelik ve Sosyal Hizmet Bölümü’nde öğrenim gören ve araştırmaya katılmayı kabul eden öğrenciler ile sınırlıdır.

\section{Bilgilendirme}

Yazarların katkı oranı beyanı şöyledir: fikir/kavram ÖÖY, DÇE, MK, İAA; tasarım ÖB, YSO, ÖK; denetleme/danışmanlık İAA; veri toplama ve işleme ÖÖY, DÇE, MK; analiz ve yorum ÖÖY, DÇE, MK, İAA; kaynak taraması: ÖÖY, DÇE, MK; makalenin yazımı: ÖÖY, DÇE, MK; eleştirel düşünme: ÖÖY, DÇE, MK, İAA; araştırmanın bütçesi: ÖÖY, DÇE, MK, İAA. Araştırma bir üniversitenin etik kurulundan (Karar No: 2017/226-271) yazılı izin, araştırma kapsamındaki öğrencilerden sözel onam alınarak yapılmıştır. Bu araştırma, kamu, ticari veya kar amacı gütmeyen sektörlerdeki finansman kuruluşlarından herhangi bir destek almamıştır. Yazarlar arasında herhangi bir çıkar çatışması bulunmamaktadır. Bu çalışmaya katılan gönüllülere teşekkür ederiz. 


\section{Kaynaklar}

1. Haylen BT, Ridder D, Freeman RM, Swift SE, Berghmans B, Lee J et al. An international urogynecological association (IUGA)/international continence society (ICS) joint report on the terminology for female pelvic floor dysfunction. Neurourol Urodynam 2010; 29: 4-20.

2. Özkan ZS, Sapmaz E. Reprodüktif çağdaki kadınlarda üriner inkontinans prevalansı ve etkileyen faktörler. Kartal Eğitim ve Araştırma Hastanesi Tıp Dergisi 2015; 26(2):101-106.

3. Yaz MP, Kurt S, Demirtaş Ö, Taşyurt A. Urinary incontinence and risk factors. Cumhuriyet Tıp Dergisi 2015;37(1):3036.

4. Schreiber Pedersen L, Lose G, Høybye MT, Elsner S, Waldmann A, Rudnicki M. Prevalence of urinary incontinence among women and analysis of potential risk factors in Germany and Denmark. Acta obstetricia et gynecologica Scandinavica 2017; 96(8): 939-948.

5. Almousa $\mathrm{S}$, van Loon AB. The prevalence of urinary incontinence in nulliparous adolescent and middle-aged women and the associated risk factors: A systematic review. Maturitas 2018; 107: 78-83.

6. Çiftçi Ö, Günay O. Kayseri eğitim ve araştırma hastanesi jinekoloji polikliniğine başvuran kadınlarda üriner inkontinans görülme sıklığı ve etkileyen faktörler. Erciyes Tıp Dergisi 2011; 33(4):301-308.

7. Yılmaz E, Muslu A, Özcan E. Üriner inkontinanslı kadınlarda yaşam kalitesi. Erciyes Üniversitesi Sağlık Bilimleri Fakültesi Dergisi 2014; 2(2): 1-14.

8. Koçak I, Okyay P, Dundar M, Erol H, Beser E. Female urinary incontinence in the west of Turkey: prevalence, risk factors and impact on quality of life. Eur Urol 2005;48: 634-641.

9. Terzi H, Terzi R, Kale A. 18 yaş üstü kadınlarda üriner inkontinans sıklığı ve etkileyen faktörler. Ege Tıp Dergisi 2013;52(1):15-19.

10. Coyne KS, Kvasz M, Ireland AM, Milsom I, Kopp ZS, Chapple CR. Urinary incontinence and its relationship to mental health and health-related quality of life in men and women in Sweden, the United Kingdom, and the United States. Eur Urol 2012;61: 88-95.

11. Peyrat L, Haillot O, Bruyere F, Boutin JM, Bertrand P, Lanson Y. Prevalence and risk factors of urinary incontinence in young and middle- aged women. BJU Int 2002; 89(1): 61-66.

12. Bardino M, Di Martino M, Ricci E, Parazzini F. Frequency and determinants of urinary incontinence in adolescent and young nulliparous women. J Pediatr Adolesc Gynecol 2015; 28(6); 462-470.

13. Visser EH, Bock GH, Kollen BJ, Meijerink M, Berger MY, Dekker JH. Systematic screening for urinary incontinence in older women: Who could benefit from it? Scand J Prim Health Care 2012;30(1), 21-28.

14. Öztürk GZ, Toprak D, Basa E. yaş üzeri kadınlarda üriner inkontinans sıklı̆̆ı ve etkileyen faktörlerin değerlendirilmesi. Şişli Etfal Hastanesi Tıp Bülteni 2012; 46(4): 170-6.

15. Strickland R. Reasonsfor not seeking care for urinary incontinence in older community-dwelling women: a contemporary review. Urologic Nursing 2014; 34(2), 63-68, 94.

16. Demir S, BEJİ NK. Üriner inkontinanslı kadınlarda yaşam kalitesi ve sağlık arama davranışları. Florence Nightingale Hemşirelik Dergisi 2015; 23(1), 23-31.

17. Szymanski KM, Cain MP, Whittam B, Kaefer M, Rink RC, Misseri R. Incontinence affects health-related quality of life in children and adolescents with spina bifida. J Pediatr Urol 2018; 14(3): 279-e1.

18. Von Gontard A, Baeyens D, Van Hoecke E, Warzak WJ, Bachmann C. Psychological and psychiatric issues in urinary and fecal incontinence. Journal Urology 2011; 185(4):1432-1436.

19. Grzeda MT, Heron J, von Gontard A, Joinson C. Effects of urinary incontinence on psychosocial outcomes in adolescence. European Child \& Adolescent Psychiatry 2017; 26(6), 649-658.

20. Mota RL. Female urinary incontinence and sexuality. International Braz J Urol 2017; 43(1): 20-28.

21. Avci İA, Öz Ö, Eren DÇ. Urinary incontinence prevalans, quality of life and awareness situations of individuals in a muslim community. International Continence Sociaty 42. Annual Meeting. September, 2017; Italy.

22. Çuhadaroğlu F. Self-esteem in adolescents [master's thesis]. Ankara, Turkey: Department of Psychiatry, Medicine Faculty, Hacettepe University; 1986.

23. Rosenberg M. Society and the adolescent self-image. Princeton, NJ: Princeton University Press; 1965.

24. Durukan H, Tok EC, Tok D ve Aytan H. Mersin ilinde, hedef popülasyonda kadınların kendisi tarafından algılanan inkontinansın görülme sıklığı ve yaş gruplarına göre inkontinans tiplerinin dağılımı. Zeynep Kamil Tıp Bülteni 2015;46: $1-5$.

25. Lasserre A, Pelat C, Gueroult V, Hanslik T, Chartier-Kastler E, Blanchon T, et al. Urinary incontinence in french women: prevalence, risk factors and impact on quality of life. Eur Urol 2009; 6: 177-183.

26. Hunskaar S, Lose G, Sykes D, Voss S. The pre- valence of urinary incontinence in women in four European countries. BJU Int 2004;93:324-30.

27. Svihra J, Luptak J, Svihrova V \& Mesko D. Gender-specific external barriers to seeking care for urinary incontinence. Patient Preference Adherence 2012; 6: 773.

28. Luo Y, Parry M, Huang YJ, Wang XH. Nursing students' knowledge and attitudes toward urinary incontinence: A crosssectional survey. Nurse Educ Today 2016;40:134-139. 
29. Natale N, Kuhn S, Siemer S, Stöckle M, Von Gontard A. Quality of life and self-esteem for children with urinary urge incontinence and voiding postponement. Journal Urology. 2009; 182(2), 692-698.

30. Fouad R, Hafez S. Elderly urinary incontinence, self esteem and quality of life. Alexandria Scientific Nursing Journal 2017; 19(1), 91-108. 